\title{
Proteomic differentiation pattern in the U937 cell line
}

\author{
Luigi Minafra $^{\mathrm{a}, 1}$, Gianluca Di Cara ${ }^{\mathrm{a}}$, Nadia Ninfa Albanese ${ }^{\mathrm{a}}$, Patrizia Cancemi ${ }^{\mathrm{a}, \mathrm{b}, *}$ \\ a Dipartimento di Oncologia Sperimentale ed Applicazioni Cliniche, Università di Palermo, Palermo, Italy \\ ${ }^{\mathrm{b}}$ Centro di Oncobiologia Sperimentale, Università di Palermo, Palermo, Italy
}

\section{A R T I C L E I N F O}

\section{Article history:}

Received 30 March 2010

Received in revised form 15 July 2010

Accepted 30 July 2010

\section{Keywords:}

U937 cell line

Proteomics differentiation markers

\begin{abstract}
A B S T R A C T
The U937 cell line, originally established from a histiocytic lymphoma, has been widely used as a powerful in vitro model for haematological studies. These cells retain the immature cell phenotype and can be induced to differentiate by several factors, among which 12-0-tetradecanoyl-13-phorbol acetate (TPA). Fully differentiated cells acquire the adherent phenotype and exhibit various properties typical of macrophages. However, in spite of a great deal of research devoted to the U937 cellular model, the molecular basis of biological processes involved in the monocyte/macrophage differentiation remains unclear. The present study has been undertaken to contribute to this knowledge, in order to identify proteomic-based differentiation pattern for the U937 cells exposed to TPA.

Present results have highlighted that the U937 cell differentiation is correlated with a significant proteomic modulation, corresponding to about $30 \%$ of the identified proteins, including both over- and down-regulated proteins. Negative modulation regarded proteins involved in the regulation of cell proliferation and in metabolic processes. Proteins appearing incremented in macrophagic phenotype include calcium- and phospholipid-binding proteins and several proteins related to the phagocytic activity.

Conclusively, we suggest that this new set of differentially expressed proteins may represent meaningful myelo-monocytic differentiation markers to be applied to the study of several haematological diseases.
\end{abstract}

(c) 2010 Elsevier Ltd. All rights reserved.

\section{Introduction}

Haematopoietic cell differentiation is driven by finely regulated signals acting on gene expression and leading to the achievement of terminally differentiated phenotypes within the proper celllineages. The underlying regulatory mechanisms that are involved in these processes are still incompletely known, while it is recognized that disturbance of one or more elements of the gene expression network can result in several neoplastic disorders.

The U937 cell line is a human haematopoietic cell line established from a generalized histiocytic lymphoma, displaying several properties of immature monocytic cells [1,2]. Since its establishment, the U937 cell line has been extensively utilized as a powerful in vitro model for the study of haematopoietic cell differentiation, blood cancer and cancer therapeutics.

\footnotetext{
* Corresponding author at: Dipartimento di Oncologia Sperimentale ed Applicazioni Cliniche, Università di Palermo, Via San Lorenzo Colli, 312, 90146 Palermo, Italy. Tel.: +39 916806706; fax: +39 916806420.

E-mail address: patriziacancemi@unipa.it (P. Cancemi).

1 Present address: Laboratorio Tecnologie Oncologiche (LATO) HSR-Giglio Cefalù (PA), Italy.
}

These immature cells can be induced to differentiate along the monocytic pathway into functionally and morphologically mature non-proliferating cells by several factors, such as: ATRA, vitamin D3 (VitD3) and 12-O-tetradecanoylphorbol-13-acetate (TPA) [3-5].

It has been widely demonstrated that the U937 cell line can only differentiate along the monocytic/macrophage pathway [6]. Differentiating U937 cells acquire adherence to substrate, reduce proliferation rates and c-Myc expression, and exhibit various properties typical of macrophages [7]. Macrophages are the major phagocytic cells and display a wide range of biosynthetic and secretory activities in response to local signals. They play a role in host defence mechanisms and contribute significantly to wound healing, acute and chronic inflammation and tumor progression (reviewed by [8]). However, in spite of these great arrays of biological processes, protein analyses that identify and characterize the cellular modifications occurring as a consequence of specific leukocyte maturation, is still incomplete. With this aim, the objective of this study was to provide new differentiation protein clusters for the myelo-monocytic U937 cell population, by 2D-IPG and mass spectrometry-based proteomics.

The results have revealed that macrophagic differentiation of the U937 cell line is associated with a proteomic modulation corresponding to about $30 \%$ of the identified proteins, including both over- and down-regulated proteins. Proteins which were found 

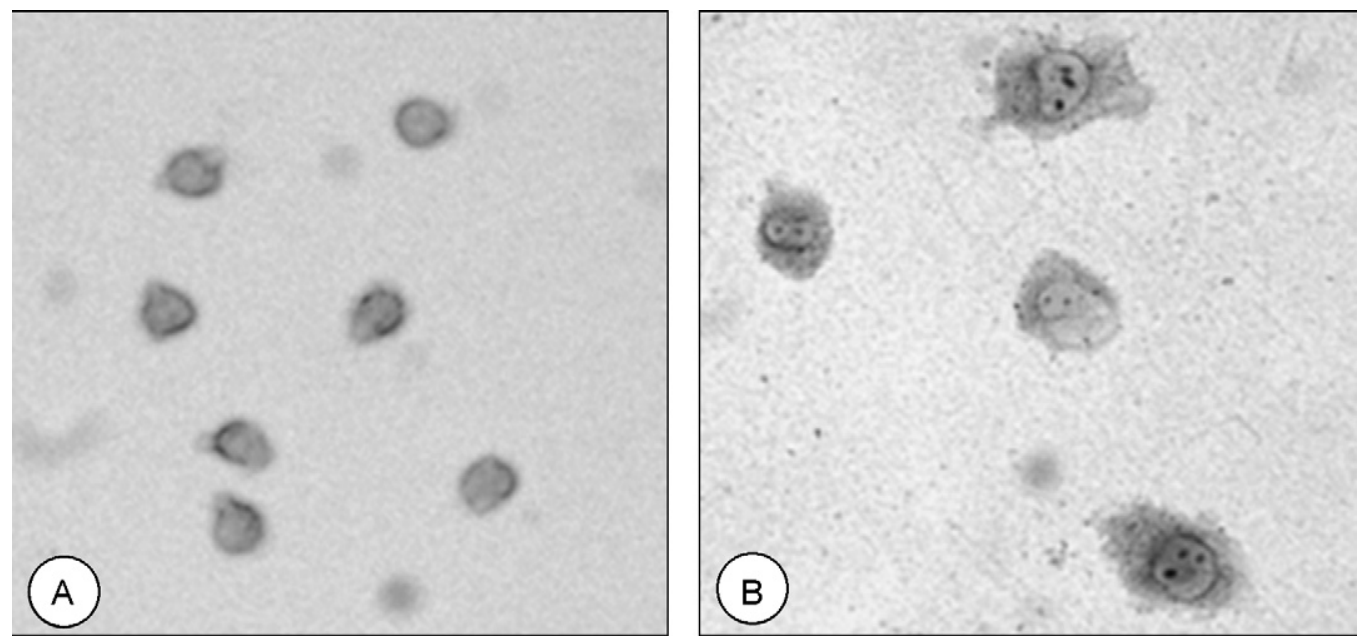

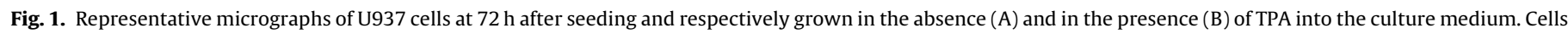
were stained with orange gold and photographed under a Jenamed 2 (Carl Zeiss Jena, Germany) light microscope, at objective magnification of $25 \times$.

incremented in the differentiated macrophagic phenotype include calcium- and phospholipid-binding proteins, as well as several proteins related to the phagocytic activity. Negative modulation regarded proteins involved in the regulation of cell proliferation and in metabolic processes.

We suggest that these protein clusters, likely corresponding to a significant group of "strategic" genes, may be relevant for the understanding of haematological diseases in which the leukocyte differentiation is impaired or compromised.

\section{Materials and methods}

\subsection{Cell culture conditions}

U937 human myelo-monocytic cells (provided by ATCC, American Type Culture Collection, Massas, VA) were seeded in T-75 cell culture flasks at concentration of $5 \times 10^{5} / \mathrm{mL}$ in RPMI- 1640 medium supplemented with $10 \%$ foetal bovine serum, $1 \%$ penicillin and $1 \%$ streptomycin. Cell differentiation was induced by incubating cells with $10 \mathrm{ng} / \mathrm{mL}(16 \mathrm{nM})$ of 12 -O-tetradecanoylphorbol-13-acetate (TPA), for $72 \mathrm{~h}$, according to the protocol of Stöckbauer et al. [5]. Proliferating control cells were cultured under the same conditions for $72 \mathrm{~h}$, in the absence of TPA. For morphologic observations, cells were stained with $0.5 \%$ orange gold and recorded under a Carl Zeiss light microscope.

\subsection{Sample preparation}

At $72 \mathrm{~h}$ after seeding, proliferating cells were removed from flasks by pipetting, centrifuged at $1000 \mathrm{rpm}$ and washed with ice-cold phosphate buffered saline (PBS) to remove serum, while the TPA-treated adherent cells were scraped from the flasks and processed separately for protein and RNA extraction.

\subsubsection{Protein extraction}

Treated and untreated cells were separately incubated on ice for $30 \mathrm{~min}$ with RIPA buffer (50 mM Tris pH 7.5, 0.1\% Nonidet P-40, 0.1\% deoxycholate, $150 \mathrm{mM} \mathrm{NaCl}$ $4 \mathrm{mM}$ EDTA) added with a mixture of protease inhibitors $(0.01 \%$ aprotinin, $10 \mathrm{mM}$ sodium pyrophosphate, $2 \mathrm{mM}$ sodium orthovanadate, $1 \mathrm{mM}$ PMSF). Cellular lysates were centrifuged at $14000 \mathrm{rpm}$ for $8 \mathrm{~min}$ to clear cell debris, and the supernatants were dialysed against ultrapure distilled water, lyophilised and stored at $-80^{\circ} \mathrm{C}$ until analysis.

Protein concentration in the cellular extracts was determined using the Bradford method [9].

\subsubsection{RNA extraction}

Total RNA from untreated and TPA-treated U937 cells was extracted using the Trizol reagent according to the manufacturer's instructions (Invitrogen). RNA concentration was determined by spectrophotometry.

\subsection{Quantitative RT-PCR analysis}

One $\mu \mathrm{g}$ of total RNA was reverse-transcribed into cDNA with Superscript II reverse transcriptase (Invitrogen) and $200 \mathrm{ng}$ of random primers in a final volume of $30 \mu \mathrm{L}$. One $\mu \mathrm{L}$ of cDNA (30 ng RNA equivalent) was analyzed by Real-Time PCR
( 1 cycle of $95^{\circ} \mathrm{C}$ for $10 \mathrm{~min}$ and 40 cycles of $95^{\circ} \mathrm{C}$ for $15 \mathrm{~s}, 60^{\circ} \mathrm{C}$ for $1 \mathrm{~min}$ ) in triplicate using SmartCycler System II instrument (Chepheid). Amplification reactions were performed in a $25 \mu \mathrm{L}$ reaction volume containing $10 \mathrm{pmol}$ of each primer and the FluoCycleTM II SYBR Green Mix (Euroclone), according to the manufacturer's specifications. Validated oligonucleotide primers for Human MYC and for Human GAPDH, which generate amplicons of $150 \mathrm{bp}$ and $108 \mathrm{bp}$ respectively, were from SABiosciences. Quantitative data were analyzed by average of triplicates Ct (cycle threshold) according to the $2^{-\Delta \Delta \mathrm{ct}}$ method and normalized versus housekeeping GAPDH gene. The data shown were generated from three independent experiments and the values are expressed relative to the c-Myc mRNA level in untreated U937 as mean $\pm \mathrm{SD}$.

\subsection{Two dimensional gel electrophoresis (2D-IPG)}

2D-IPG was performed essentially as described [10]. Aliquots of the dried cell lysate were solubilised in a buffer containing 4\% CHAPS, $40 \mathrm{mM}$ Tris, $65 \mathrm{mM}$ DTE (1,4-dithioerythritol) and a trace amount of bromophenol blue in $8 \mathrm{M}$ urea. The first dimensional separation was performed at $20^{\circ} \mathrm{C}$ on commercial sigmoidal immobilised $\mathrm{pH}$ gradient strips (IPG), $18 \mathrm{~cm}$ long with pH range $3.0-10$, (Pharmacia). Strips were rehydrated in $8 \mathrm{M}$ urea, $2 \%$ CHAPS, $10 \mathrm{mM}$ DTE and $0.5 \%$ carrier ampholytes (Resolyte 3.5-10). Aliquots of $45 \mu \mathrm{g}$ (analytical gels) or $1.5 \mathrm{mg}$ (preparative gels) of total proteins were applied to the gel strip. The isoelectrofocusing was carried out by linearly increasing voltage from 200 to $3500 \mathrm{~V}$ during the first $3 \mathrm{~h}$, after which focusing was continued at $8000 \mathrm{~V}$ for $8 \mathrm{~h}$. After the run the IPG strips were equilibrated with a solution containing $6 \mathrm{M}$ urea, $30 \%$ glycerol, $2 \% \mathrm{SDS}, 0.05 \mathrm{M}$ Tris- $\mathrm{HCl}$ pH 6.8 and $2 \%$ DTE for $12 \mathrm{~min}$. The $-\mathrm{SH}$ groups were then blocked by substituting the DTE with $2.5 \%$ iodoacetamide in the equilibrating buffer. The focused proteins were then separated on 9-16\% linear gradient polyacrylamide gels (SDS-PAGE) with a constant current of $40 \mathrm{~mA} / \mathrm{gel}$ at $10^{\circ} \mathrm{C}$. Gels were stained with ammoniacal silver nitrate, digitised using a computing densitometer and processed with Image-Master 2D Platinum system (Amersham Biosciences).

\subsection{Matrix-assisted laser desorption ionization-time of flight (MALDI-TOF)}

Mass spectrometric sequencing was carried out after in-gel digestion of protein spots, using sequencing-grade trypsin $(20 \mu \mathrm{g} / \mathrm{vial})$, according to the method of Shevchenko et al. [11] with some modifications. The tryptic peptide extracts were dried in a vacuum centrifuge and re-dissolved in $10 \mu \mathrm{L}$ of $0.1 \%$ trifluoroacetic acid (TFA). The matrix, a-cyano-4-hydroxycinnamic acid (HCCA), was purchased from Sigma-Aldrich. A saturated solution of HCCA $(1 \mu \mathrm{L})$ at $2 \mathrm{mg} / 200 \mu \mathrm{L}$ in $\mathrm{CH} 3 \mathrm{CN} / \mathrm{H}_{2} \mathrm{O}$ $(50 / 50(\mathrm{v} / \mathrm{v}))$ containing $0.1 \%$ TFA was mixed with $1 \mu \mathrm{L}$ of peptide solution on the MALDI plate and left to dry. MALDI-TOF mass spectra were recorded on a Voyager DE-PRO (Applied-Biosystems) mass spectrometer, in the 500-5000 Da mass range, using a minimum of 100 shots of laser per spectrum. Delayed extraction source and reflector equipment allowed sufficient resolution to consider $\mathrm{MH}^{+}$of monoisotopic peptide masses. Internal calibration was done using trypsin autolysis fragments at $\mathrm{m} / z$ 842.5100, 1045.5642 and 2211.1046 Da. Peptide mass fingerprinting was compared to the theoretical masses from the Swiss-Prot or NCBI sequence databases using Mascot (http://www.matrixscience.com/). Typical search parameters were as follows: $\pm 50 \mathrm{ppm}$ of mass tolerance, carbamidomethylation of cysteine residues, one missed enzymatic cleavage for trypsin, a minimum of four peptide mass hits was required for a match, methionine residues could be considered in oxidized form. 


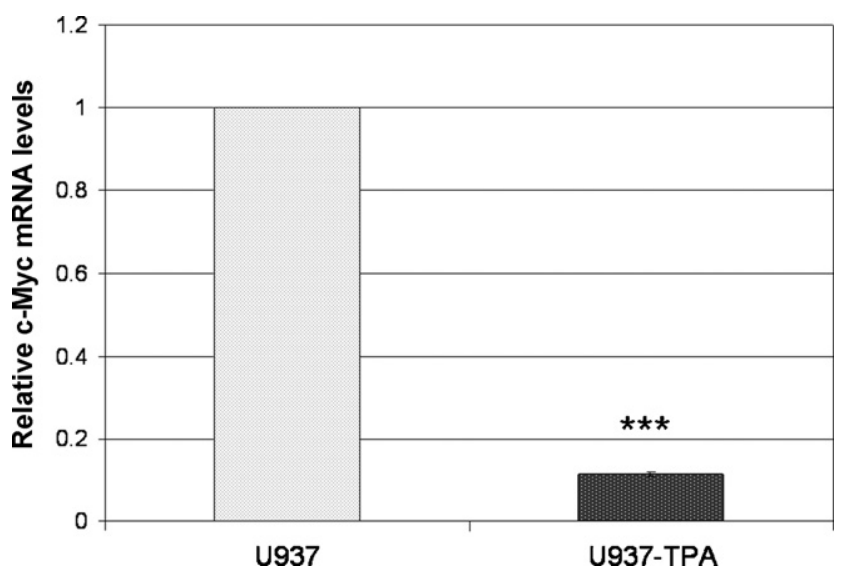

Fig. 2. Quantitative RT-PCR (Real-Time) shows a 10-fold decrement of the c-Myc mRNA in TPA-treated U937cells. The results are expressed relative to the c-Myc mRNA level in untreated U937 cells. Data are mean \pm SD of three independent experiments. ${ }^{* * *} p<0.001$.

\subsection{Western blotting}

For immune detection the 1D-gels were electrotransferred onto nitrocellulose membrane (HyBond ECL, Amersham) and stained with Ponceau S (Sigma). The membranes were then probed with the following antibodies: anti-CD206 (monoclonal, Santa Cruz), anti-CD14 (monoclonal, Santa Cruz), anti-ACTB (monoclonal IgM, Oncogene), anti-GELS (monoclonal, Santa Cruz), anti-CALR (monoclonal, Abcam), anti-FABP5 (polyclonal, Santa Cruz), anti-NDK (monoclonal, Santa Cruz), anti-S100A4 (monoclonal, Santa Cruz), anti-S100A11 (polyclonal, Santa Cruz), anti-S100A13 (polyclonal, Santa Cruz), anti-ANXA2 (monoclonal, BD Biosciences), anti-ANXA5 (monoclonal, Santa Cruz) and anti-LEG1 (monoclonal, Novus Biologicals). Following incubation with the proper secondary peroxidase-linked antibody, the reaction was revealed by the ECL detection system, using high performance films (Hyperfilm ECL, Amersham).

\section{Results}

\subsection{Cell morphology}

Fig. 1 shows two representative micrographs of U937 cells at $72 \mathrm{~h}$ after seeding and respectively grown in the absence (A) and in the presence (B) of TPA into the culture medium. The culture depicted in A shows cells still proliferating, roundish and floating

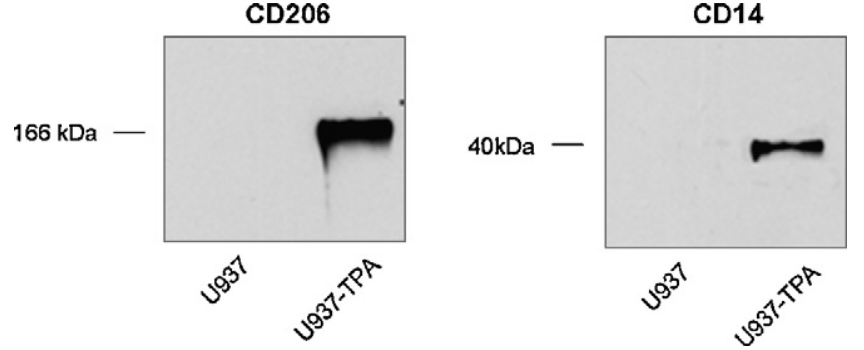

Fig. 3. Western blot analyses of the expression of CD206 and CD14 in U937 proliferating and TPA-treated cells.

into the medium. Cells of the culture shown in B display the flatten morphology of differentiated macrophage-like cells, fully adherent to the substrate.

\section{2. c-Myc expression}

In order to ascertain if the transition from floating to adherent cells was associated with c-Myc down-regulation, as reported in literature [6,12], we submitted the untreated and TPA-treated U937 cells to total RNA extraction and quantitative RT-PCR analyses (Real-Time PCR, as described in Section 2). As shown in Fig. 2, there is a 10-fold decrement of the c-Myc expression following the differentiative event in TPA-treated U937 cells.

\subsection{Immunological phenotyping}

To verify if the U937-TPA driven differentiation was also associated with the expression of macrophage-selective markers, we performed Western blot analyses with monoclonal antibody antiCD206 (MR) and anti-CD14 antigens.

The human mannose receptor CD206 (MR) is a $175 \mathrm{kDa}$ transmembrane glycoprotein characterized by eight N-linked glycosylation sites and eight C-type lectin carbohydrate recognition domains [13]. Its role in phagocytosis of mannose-coated particles, in endocytosis of mannosylated glycoproteins or in receptormediated facilitated antigen presentation, has been recognized by several authors [14-16]. The CD14 antigen is a GPI-linked glycopro-
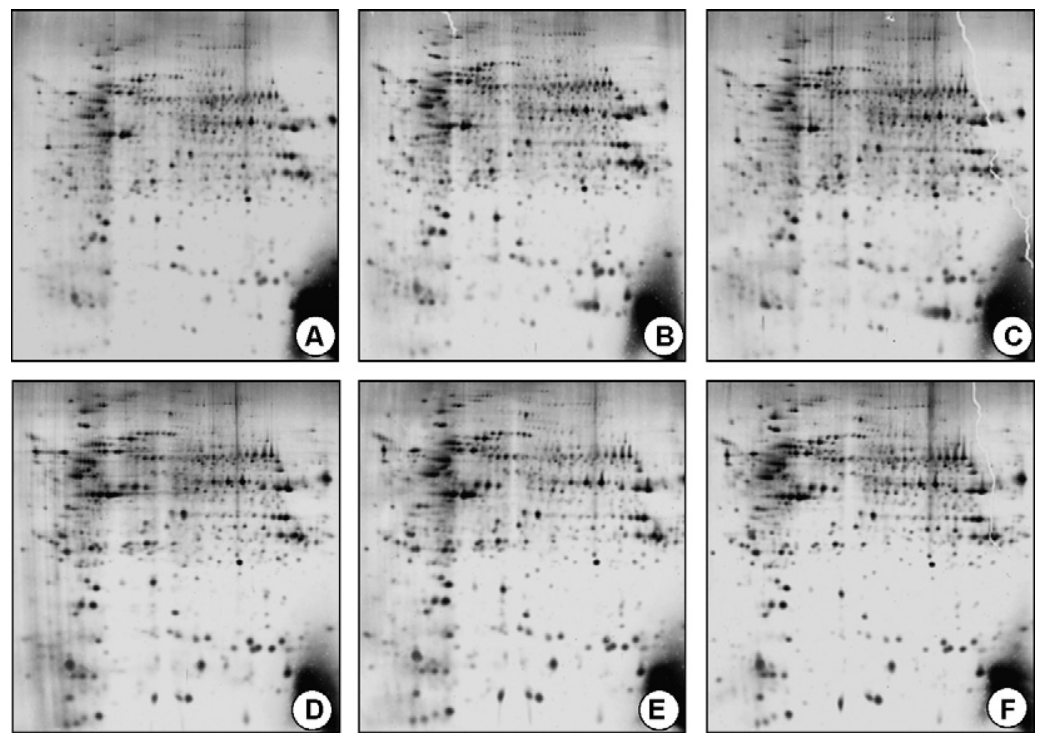

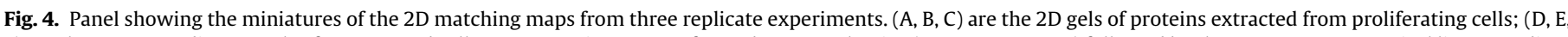

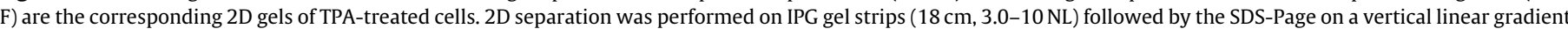
slab gel (9-16\%T). 

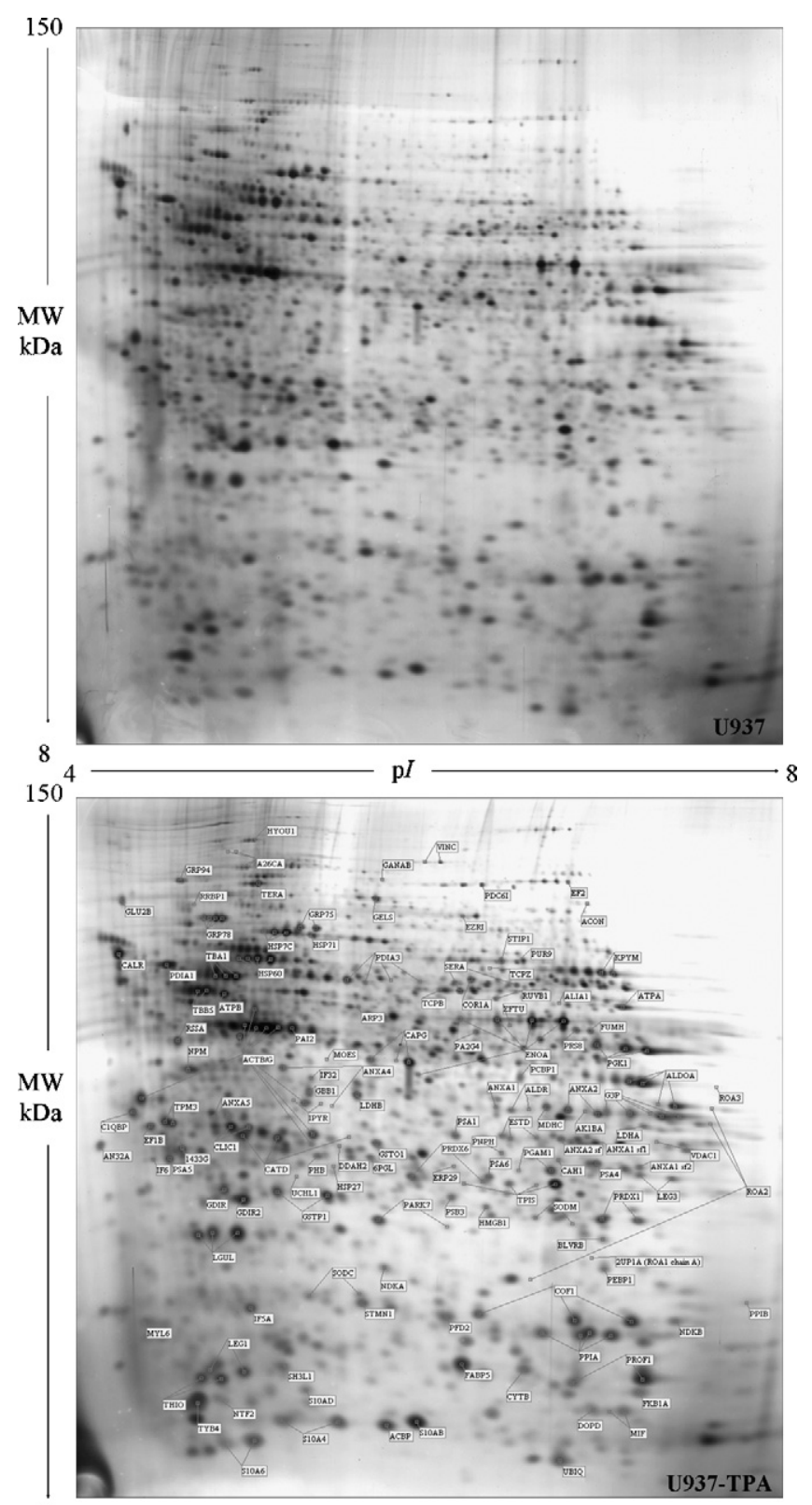

8

Fig. 5. Representative proteomic maps of protein extracts from proliferating (A) and differentiated cells (B). Protein spots of known identity are labelled with the abbreviated name of the Swiss-Prot database. When present, different isoforms of the same protein are jointly labelled.

tein of $55 \mathrm{kDa}$, expressed on cells of the myelo-monocytic lineage including macrophages and Langerhans cells.

As shown in Fig. 3, immune reactions for both CD206 and CD14 were only detected in the adherent-TPA-treated U937 cells, therefore indicating the achievement of the macrophage phenotype in response to the TPA.

\subsection{Qualitative proteomics}

Undifferentiated and macrophage-differentiated cells, both at $72 \mathrm{~h}$ from seeding, were processed and submitted to 2D-IPG separation as described in Section 2. Fig. 4 shows the miniatures of $2 \mathrm{D}$ maps of protein extracts from proliferating $(A, B, C)$ and differentiated U937 cells (D, E, F), obtained from triplicate experiments.

Fig. 5 reports two representative maps of protein extracts from proliferating (A) and differentiated cells (B), where the protein identities are marked with labels corresponding to the abbreviated name of the Swiss-Prot database. The different isoforms of the same protein, when present, are jointly labelled. In the present study we have identified or confirmed by mass spectrometry 216 protein forms corresponding to 133 genes.

As shown in Fig. 6A, the identified proteins were grouped into 10 functional clusters essentially according to David gene Ontology database [17], with the abrogation of the redundancy, choosing to select among the suggested categories the ones with the highest Benjamini score. Proteins with multifunctional activities were sorted according to their major function (10). The functional categories include: (1) cytoskeleton proteins; (2) metabolic processes; (3) chaperones and folding proteins; (4) regulation of cell proliferation; (5) cell signalling; (6) calcium/phospholipid-binding proteins; (7) binding proteins; (8) oxidoreductase activity proteins; (9) catabolic processes; (10) gene expression.

\subsection{Quantitative proteomics}

To compare the pattern and intensity of protein expression between the paired samples of proliferating and differentiated cells, we applied the densitometric algorithm of the Image-Master software, using the Vol\% parameter to normalize spot density values. The average of three spot values, from three different gels, was utilized to perform relative quantification of protein levels.

Protein levels were considered significantly different for $\geq 1.5$ fold change and highly significant for $\geq 2$-fold change. As it is shown in the pay-graph in Fig. 6B, over the 216 identified proteins, 63 proteins (29\%) appeared modulated following differentiation: 31 of them (49\%) were up-regulated and 32 (51\%) were down-regulated with respect to proliferating U937. The catalogue of these proteins is presented in Table 1 with the following information: protein name, access number of Swiss-Prot database, protein abbreviated names, theoretical $\mathrm{pI}$ and MW, number of peptide matches that covered regions of the protein sequence.

The panels in Fig. 7 shows the histograms illustrating the relative differences in density values (expressed as Vol\%) of modulated protein spots, sorted by functional categories.

1. Cytoskeleton proteins. This group of proteins contains 35 protein forms, including structural and regulative proteins. In the histogram are represented the 10 proteins responsive to differentiation, 4 of which at fold change value $\geq 2$ and with $p$-value $<0.05$ (Fig. 7A). However two of them represent isoforms of actin, one of which decreases while the other increases, leaving the actin content of cells unchanged. The two other highly modulated proteins are gelsolin and tropomysin, two actin-binding proteins which cooperate in controlling the microfilament system [18].

2. Metabolic processes. The proteins that we included in this category can be sub-classified as glycolitic enzymes, mitochondrial enzymes and others. This class represents the most abundant containing 51 protein forms. Thirteen members of this group appeared modulated and plotted in the histogram (Fig. 7B). Interestingly all the modulated forms were down-regulated, testifying a slowing-down of metabolism during the differentiation.

3. Chaperones and folding proteins. This class included 31 protein forms, 7 of which appeared modulated, 4 at high level and with $p$-value $<0.05$ (Fig. 7C). The latter included 3 proteins upregulated (CALR, GRP94, HYOU1) and 1 down-regulated (PPIB).

4. Regulation of cell proliferation. This group contains 10 unique proteins, 4 of them modulated (Fig. 7D), but only 2 significantly down-regulated, with at fold change value $\geq 2$ and with p-value < 0.05: these are the NDKB and RUVB1. 
Table 1

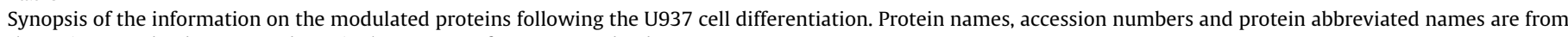
the Swiss-Prot database; $\mathrm{pI}$ and nominal masses are from Mascot database.

\begin{tabular}{|c|c|c|c|c|c|c|}
\hline Protein name & AC number & Abbreviated name & $\mathrm{pI}$ value & Nominal Mass & \% Masses matched & $\begin{array}{l}\text { Sequence } \\
\text { coverage (\%) }\end{array}$ \\
\hline 14-3-3 Protein gamma & P61981 & $1433 G$ & 4.80 & 28,456 & $14 / 18(78 \%)$ & 41 \\
\hline $\begin{array}{l}60 \text { kDa heat shock protein, } \\
\text { mitochondrial }\end{array}$ & P10809 & HSP60 d & 5.27 & 59,500 & $15 / 19(78 \%)$ & 39 \\
\hline 6-phosphogluconolactonase & 095336 & 6PGL & 5.70 & 27,815 & $6 / 6(100 \%)$ & 30 \\
\hline 94 kDa glucose-regulated protein & P14625 & GRP94 & 4.76 & 92,469 & $14 / 28(50 \%)$ & 30 \\
\hline $\begin{array}{l}\text { Acidic leucine-rich nuclear } \\
\text { phosphoprotein } 32 \text { family member A }\end{array}$ & P39687 & AN32A & 3.99 & 28,682 & $10 / 32(31 \%)$ & 30 \\
\hline Actin, cytoplasmic 1 & P60709 & ACTB & 5.29 & 42,052 & $6 / 7(86 \%)$ & 19 \\
\hline Actin, cytoplasmic 1 & P60709 & ACTB e & 5.29 & 42,052 & $7 / 14(50 \%)$ & 18 \\
\hline Actin, cytoplasmic 1 & P60709 & ACTB fr & 5.29 & 42,052 & $5 / 10(50 \%)$ & 13 \\
\hline Acyl-CoA-binding protein & P07108 & ACBP & 6.12 & 10,038 & $4 / 5(80 \%)$ & 50 \\
\hline Aldose reductase & P15121 & ALDR a & 6.51 & 36,230 & $17 / 142(12 \%)$ & 38 \\
\hline Annexin A1 & P04083 & ANXA1 & 6.57 & 38,918 & $11 / 37(30 \%)$ & 44 \\
\hline Annexin A2 & P07355 & ANXA2 a & 7.57 & 38,808 & $11 / 24(46 \%)$ & 29 \\
\hline Annexin A2 b & P07355 & ANXA2 b & 7.57 & 38,808 & $17 / 93(18 \%)$ & 41 \\
\hline Annexin A5 & P08758 & ANXA5 a & 4.94 & 35,971 & $20 / 38(53 \%)$ & 64 \\
\hline Annexin A5 & P08758 & ANXA5 b & 4.94 & 35,971 & $7 / 12(58 \%)$ & 21 \\
\hline $\begin{array}{l}\text { ATP synthase subunit beta, } \\
\text { mitochondrial }\end{array}$ & P06756 & ATPB & 5.05 & 50,405 & $31 / 35(89 \%)$ & 59 \\
\hline Calreticulin & P27797 & CALR & 4.29 & 48,283 & $13 / 45(29 \%)$ & 35 \\
\hline Carbonic anhydrase 1 & P00915 & CAH1 & 6.59 & 28,809 & $7 / 10(70 \%)$ & 40 \\
\hline Cathepsin D & P07339 & CATD a & 6.10 & 45,037 & $6 / 8(75 \%)$ & 19 \\
\hline $\begin{array}{l}\text { Complement component } 1 \mathrm{Q} \\
\text { subcomponent-binding protein, } \\
\text { mitochondrial }\end{array}$ & Q07021 & C1QBP & 4.74 & 31,742 & $9 / 57(16 \%)$ & 37 \\
\hline Coronin-1A & P31146 & COR1A & 6.25 & 51,678 & $9 / 14(64 \%)$ & 23 \\
\hline Fatty acid-binding protein, epidermal & Q01469 & FABP5 & 6.60 & 15,497 & $10 / 52(19 \%)$ & 57 \\
\hline Galectin-1 & P09382 & LEG1 & 5.34 & 15,048 & $5 / 9(56 \%)$ & 31 \\
\hline Gelsolin & P06396 & GELS & 5.90 & 86,043 & $33 / 33(100 \%)$ & 40 \\
\hline Glucosidase 2 subunit beta & P14314 & GLU2B & 4.33 & 60,357 & $9 / 38(24 \%)$ & 20 \\
\hline Glutathione S-transferase P & P09211 & GSTP1 & 5.43 & 23,569 & $5 / 7(71 \%)$ & 34 \\
\hline $\begin{array}{l}\text { Glyceraldehyde-3-phosphate } \\
\text { dehydrogenase }\end{array}$ & P04406 & $\mathrm{G} 3 \mathrm{~Pa}$ & 8.57 & 36,201 & $8 / 11(73 \%)$ & 26 \\
\hline Heat shock 70 kDa protein 1 & P08107 & HSP71 & 5.48 & 70,052 & $19 / 50(38 \%)$ & 38 \\
\hline $\begin{array}{l}\text { Heterogeneous nuclear } \\
\text { ribonucleoprotein } \mathrm{A} 3\end{array}$ & P51991 & ROA3 & 9.10 & 39,799 & $5 / 11(45 \%)$ & 13 \\
\hline Hypoxia up-regulated protein 1 & Q9Y4L1 & HYOU1 & 5.16 & 111,494 & $12 / 19(63 \%)$ & 20 \\
\hline Inorganic pyrophosphatase & Q15181 & IPYR & 5.54 & 33,095 & $12 / 30(40 \%)$ & 48 \\
\hline $\begin{array}{l}\text { Macrophage migration inhibitory } \\
\text { factor }\end{array}$ & P14174 & MIF b & 7.74 & 12,639 & $4 / 5(80 \%)$ & 21 \\
\hline Myosin light polypeptide 6 & P60660 & MYL6 & 4.43 & 14,537 & $10 / 17(58 \%)$ & 60 \\
\hline Nucleoside diphosphate kinase B & P22392 & NDKB & 8.52 & 17,401 & $9 / 28(32 \%)$ & 59 \\
\hline Peptidyl-prolyl cis-trans isomerase A & P62937 & PPIA a & 7.68 & 18,229 & $9 / 14(64 \%)$ & 50 \\
\hline Peptidyl-prolyl cis-trans isomerase B & P40227 & PPIB & 9.33 & 22,785 & $17 / 20(85 \%)$ & 49 \\
\hline $\begin{array}{l}\text { Phosphatidylethanolamine-binding } \\
\text { protein } 1\end{array}$ & P30086 & PEBP1 & 7.01 & 21,158 & $5 / 15(33 \%)$ & 36 \\
\hline Phosphoglycerate mutase 1 & P18669 & PGAM1 a & 6.67 & 28,900 & $9 / 34(26 \%)$ & 43 \\
\hline Plasminogen activator inhibitor 2 & P05120 & PAI2 & 5.46 & 46,596 & $22 / 30(73 \%)$ & 36 \\
\hline POTE ankyrin domain family member E & Q6S8J3 & A26CA a & 5.83 & 122,882 & $15 / 18(83 \%)$ & 14 \\
\hline Profilin-1 & P07737 & PROF1 a & 6.97 & 12,118 & $5 / 7(71 \%)$ & 40 \\
\hline Proteasome subunit alpha type- 4 & P25789 & PSA4 & 7.57 & 29,750 & $10 / 62(16 \%)$ & 48 \\
\hline Proteasome subunit alpha type- 6 & P60900 & PSA6 & 6.34 & 27,838 & $10 / 26(28 \%)$ & 35 \\
\hline Protein S100-A11 & P31949 & S100A11 & 6.56 & 11,847 & $5 / 6(83 \%)$ & 34 \\
\hline Protein S100-A13 & Q99584 & S100A13 & 5.91 & 11,464 & $13 / 19(68 \%)$ & 89 \\
\hline Protein S100-A4 & P26447 & $\mathrm{S} 10 \mathrm{~A} 4 \mathrm{a}$ & 5.85 & 11,949 & $4 / 4(100 \%)$ & 57 \\
\hline Protein S100-A4 & P26447 & $\mathrm{S} 10 \mathrm{~A} 4 \mathrm{~b}$ & 5.85 & 11,949 & $4 / 4(100 \%)$ & 27 \\
\hline Protein S100-A6 & P06703 & S10A6 a & 5.33 & 10,230 & $4 / 4(100 \%)$ & 28 \\
\hline Protein S100-A6 & P06703 & S10A6 b & 5.33 & 10,230 & $4 / 4(100 \%)$ & 26 \\
\hline Purine nucleoside phosphorylase & P00491 & PNPH & 6.45 & 32,325 & $15 / 25(60 \%)$ & 50 \\
\hline Retinal dehydrogenase 1 & P00352 & AL1A1 & 6.80 & 50,405 & $21 / 34(61 \%)$ & 49 \\
\hline RuvB-like 1 & Q9Y265 & RUVB1 & 6.02 & 50,538 & $7 / 15(47 \%)$ & 25 \\
\hline S-Formylglutathione hydrolase & P10768 & ESTD a & 6.54 & 31,956 & $8 / 48(17 \%)$ & 25 \\
\hline S-Formylglutathione hydrolase & P10768 & ESTD b & 6.54 & 31,956 & $5 / 24(21 \%)$ & 23 \\
\hline S-Formylglutathione hydrolase & P10768 & ESTD c & 6.54 & 31,956 & $16 / 90(18 \%)$ & 72 \\
\hline Stathmin & P16949 & STMN1 & 5.76 & 17,292 & $5 / 5(100 \%)$ & 41 \\
\hline Superoxide dismutase $[\mathrm{Cu}-\mathrm{Zn}]$ & P00441 & SODC a & 5.70 & 16,154 & $5 / 6(83 \%)$ & 42 \\
\hline $\begin{array}{l}\text { Superoxide dismutase [Mn], } \\
\text { mitochondrial }\end{array}$ & P04179 & SODM b & 8.35 & 24,707 & $7 / 35(20 \%)$ & 38 \\
\hline Triosephosphate isomerase & P60174 & TPIS c & 6.45 & 26,938 & $5 / 33(15 \%)$ & 28 \\
\hline Triosephosphate isomerase & P60174 & TPIS d & 6.45 & 26,938 & $9 / 42(21 \%)$ & 52 \\
\hline Tropomyosin alpha 3 chain & P06753 & ТРМ3 а & 4.68 & 32,856 & $7 / 8(88 \%)$ & 27 \\
\hline Tropomyosin alpha 3 chain & P06753 & ТРM3 b & 4.68 & 32,856 & $10 / 14(71 \%)$ & 30 \\
\hline Tubulin alpha- 1 chain & P68366 & TBA1 a & 5.10 & 54,581 & $19 / 33(57 \%)$ & 51 \\
\hline
\end{tabular}



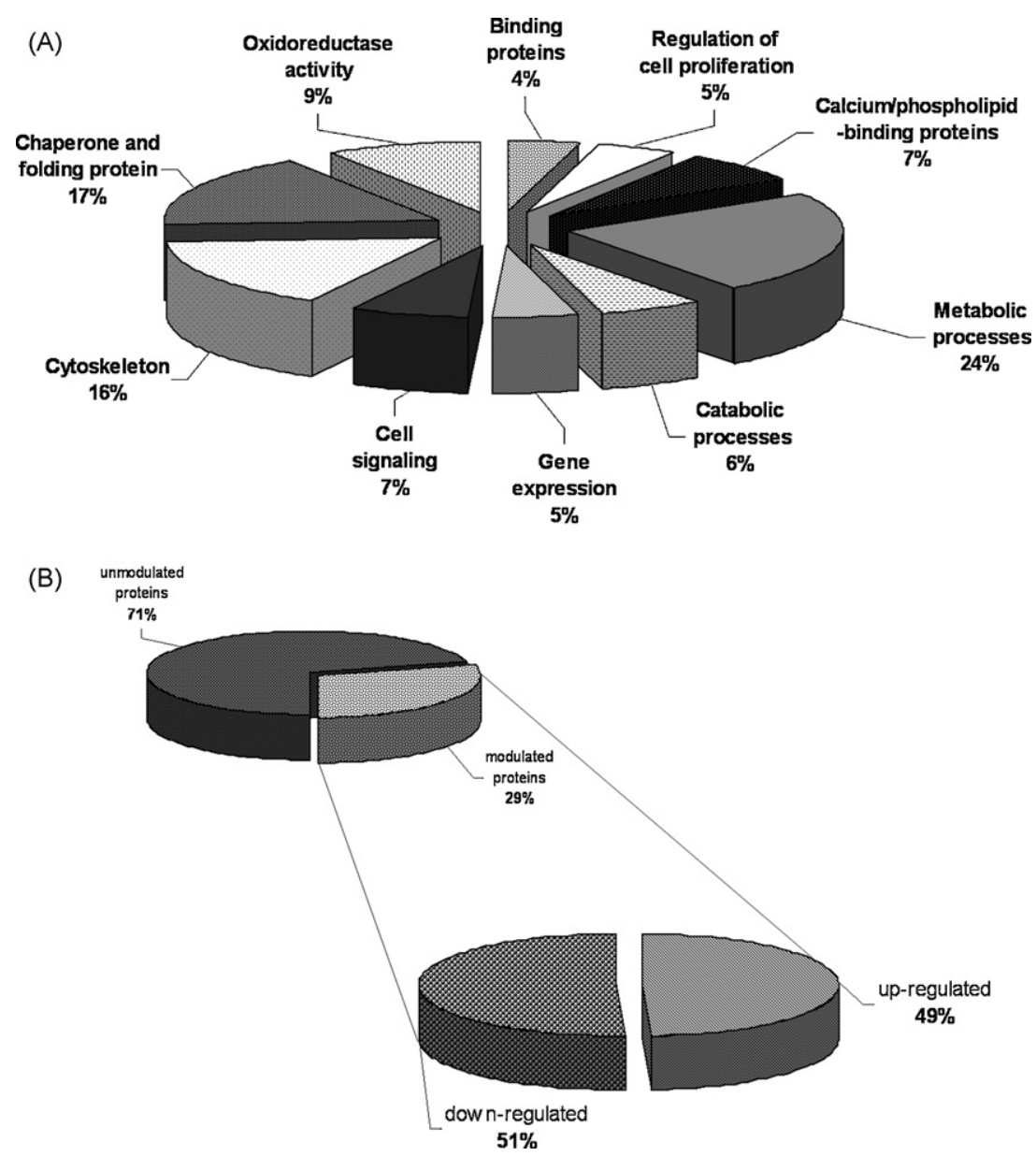

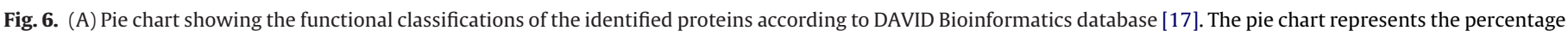
of identified proteins under each category. (B) Pie-graph showing the percentage of modulated and un-modulated proteins after TPA treatment.

5. Cell signalling. This category contains 15 proteins. In the histogram are represented the 5 of them which are modulated (Fig. 7E), 4 at high level and with $p$-value $<0.05,3$ positively (AN32A, GLU2B, LEG1) and 1 negatively (STMN1).

6. Calcium/phospholipid-binding proteins. This category contains 16 proteins belonging to 2 protein families: the $S 100$ and the Annexins. Interestingly, this is the most modulated functional category, in fact, 10 of them ( $6 \mathrm{~S} 100$ s and 4 Annexins), appeared modulated at high level and with $p$-value $<0.05$ (Fig. 7F).

7. Binding proteins. This is a small group formed by 9 proteins, 4 modulated and 3 significantly: ACBP, C1QBP FABP5 with $p$ value $<0.05$ (Fig. 7G).

8. Oxidoreductase activity proteins. Besides the metabolic processes, oxyreduction is an intense cellular activity, even for in vitro cultures. Indeed the number of protein belonging to this group are 20, but only 5 appear to be modulated, 2 of which at high level and with $p$-value $<0.05$ (ALIA1, GSTP1) (Fig. 7H).

9. Catabolic processes. This group contains 13 proteins. Four of them are modulated, only 2 at high level and with $p$ value $<0.05$, namely a subunit of proteosome (PSA6) which is down-regulated and PAI2 which is incremented (Fig. 7I).

10. Gene expression. Finally this group of proteins includes 11 proteins, but none of them appeared modulated.

\subsection{Western blot validation of selected proteins}

Immunological assays were performed to confirm the results obtained by peptide mass fingerprinting in relation to a set of pro- teins responsive to the TPA treatment, namely: ACTB, GELS, CALR, FABP5, NDK, S100A4, S100A11, S100A13, ANXA2, ANXA5 and LEG1. The Fig. 8 shows a panel of cropped protein spots from triplicate 2D gels performed in parallel on untreated and treated U937 cells. In the box at the bottom of the $2 \mathrm{D}$ images is reported for each protein the paired 1D-WB with the proper antibody, showing the optimal correspondence between the silver stained spots and the immunological revelation. It is worth to notice that the overall amount of reactive actin remains almost unchanged between treated and untreated cells, confirming that the variations in actin isoforms, observed in the proteomic maps, are reciprocally compensated.

\section{Discussion}

This study represents a contribution to the widespread effort for making progress in the collection and integration of proteomics data with biomedical and clinical data, having as major goal the identification of proteins or genes with critical roles in relevant pathways involved in differentiation and cancer. The present results have highlighted interesting proteomics changes, not described before, occurring as a consequence of the TPAinduced differentiation of the myelo-monocytic cells U937. Firstly, we ascertained the fully differentiation of U937, after the exposure to TPA, by morphological monitoring of the phenotypic changes and by measuring the expression levels of the c-Myc gene as representative marker of U937 cell proliferation. The time lapse of $72 \mathrm{~h}$ was chosen as the optimal completion time for the differentiation event, which associates with cell adhesion of the majority 
(A)

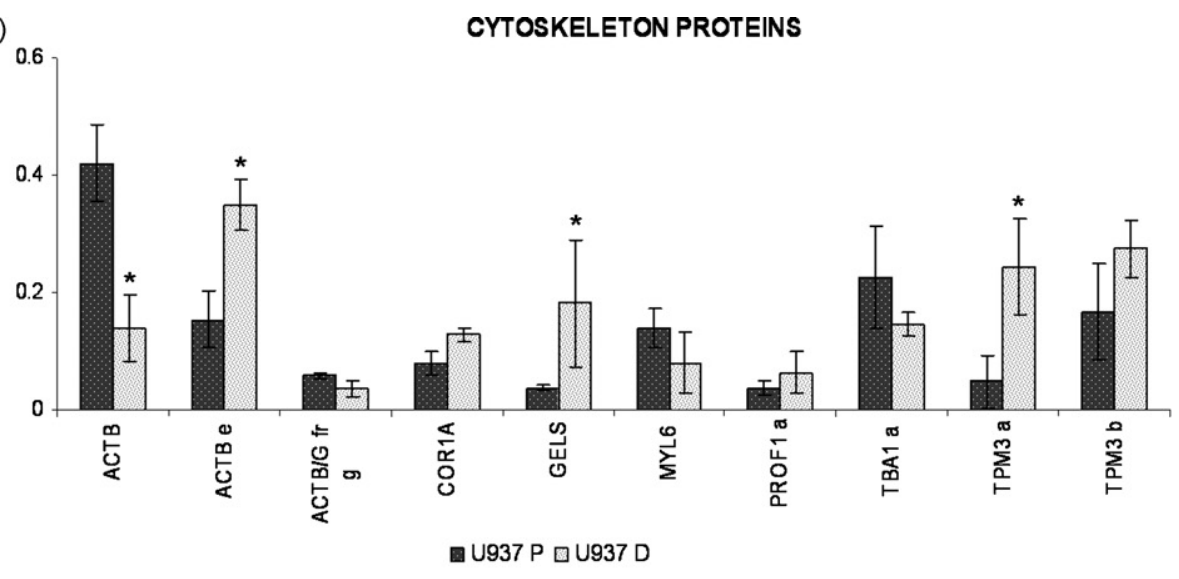

(B)

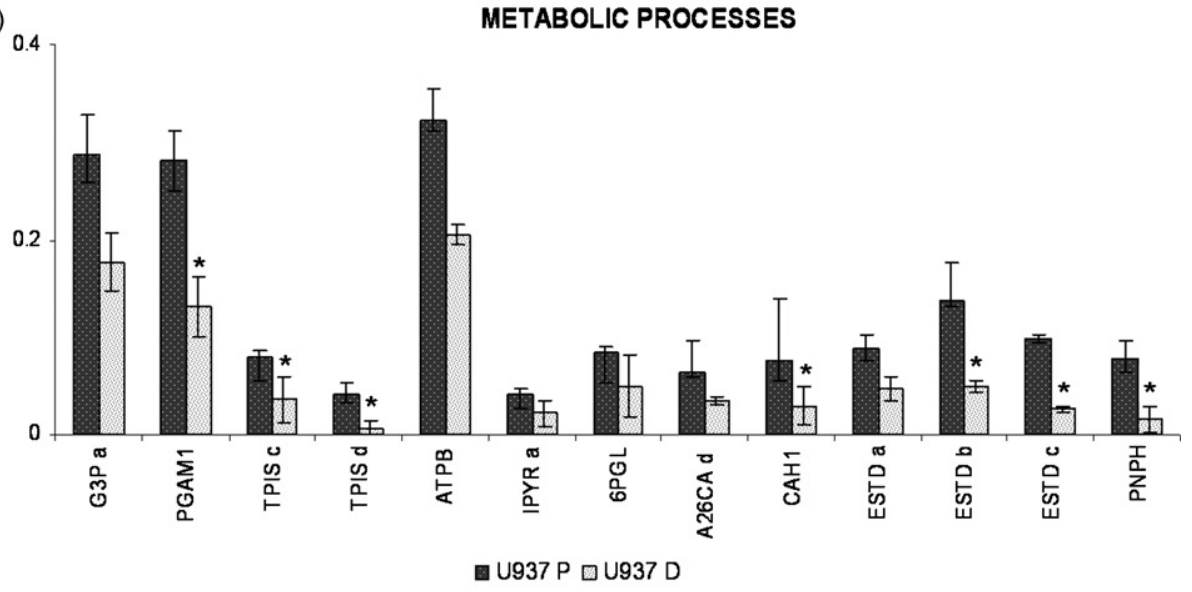

(C)

CHAPERONES AND FOLDING PROTEINS

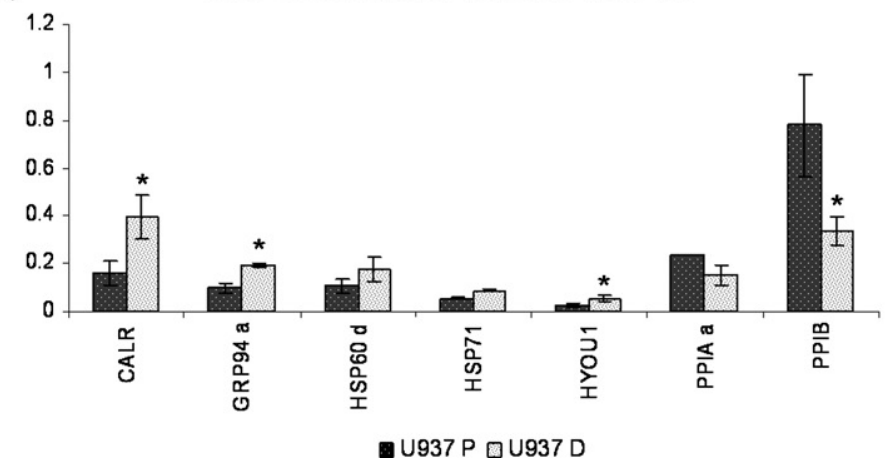

Fig. 7. Histograms of modulated proteins in U937 proliferating and TPA-treated cells. The modulated proteins are grouped in the functional categories, according to their primary biological functions. Relative intensity of protein spots was calculated normalizing the data to the sum of all spot volumes on gels (Vol\%). Each value is the mean of three independent determinations. Vertical bars indicate SD values. According to general criteria for gene expression amplitude, the degree of the modulation was considered significant for fold values $\geq$ of 1.5 , and highly significant (tagged with ") for fold values $\geq 2$. The Student's $t$-test confirmed the statistical validity of the fold change. The data in the graphs are expressed as mean number \pm SD.

of cells in culture. Two macrophage-selective markers were chosen to validate the U937 cell differentiation: CD206 and CD14. The first is a mannose receptor whose expression has been regarded as a differentiation hallmark from immature to differentiated monocytes.

CD14 antigen is a receptor for bacterial lipopolysaccharide (LPS) and the lipopolysaccharide binding protein (LBP). LBP and CD14 act synergically (as opsonin and opsonic receptor, respectively) to promote the macrophage phagocytosis [19].

Concerning the proteomic profiling, it is of interest to notice that about $30 \%$ of the proteins undergoes positive or negative modula- tions during the differentiative event. Under- and over-expression of the identified proteins are balanced, but worthy of note is that for some classes the responses to differentiation are consistent. This is the case of the proteins belonging to the large group of metabolic processes, in which the majority of them remains unchanged while a minor group of them respond negatively. This provides evidence that the transition from a proliferation state to a differentiated one, is associated with a decrease of metabolic activities. Conversely, the proteins involved in cell signalling appear either unchanged or even positively modulated, testifying a plenty vitality of the differentiated cells. 
(D)

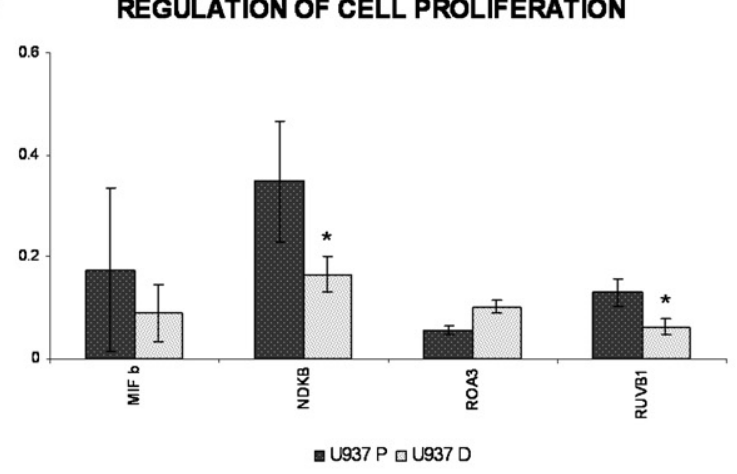

(F)

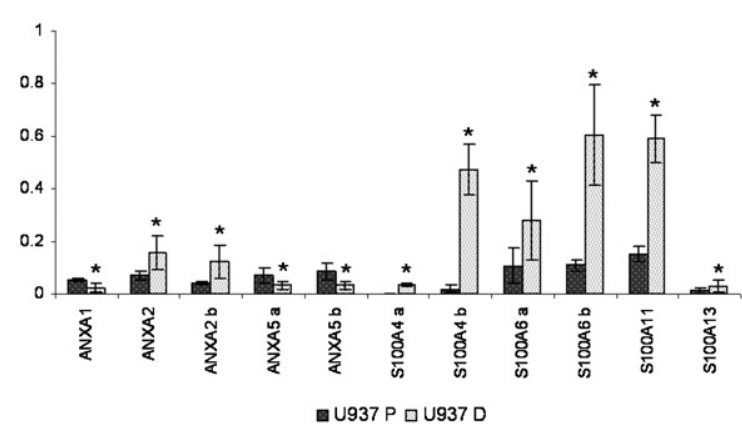

(H)

OXIDOREDUCTASE ACTIVITY PROTEINS

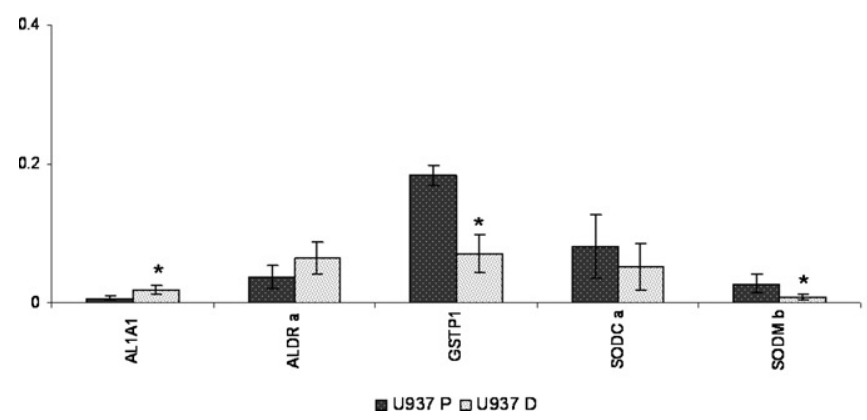

(E)

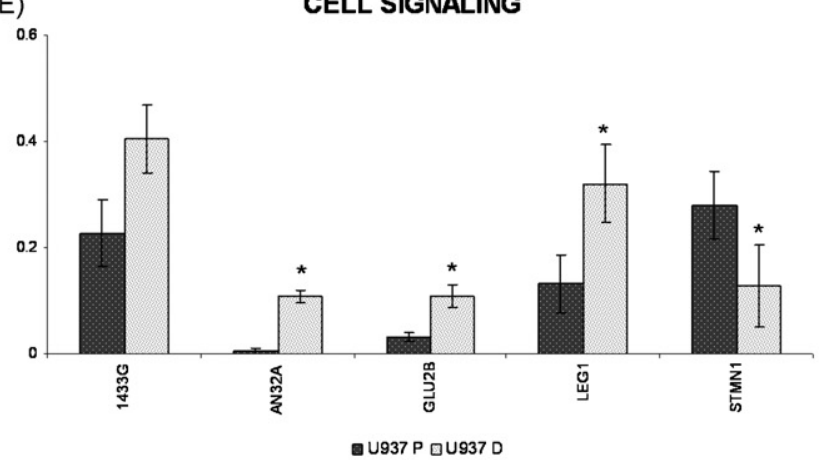

(G)

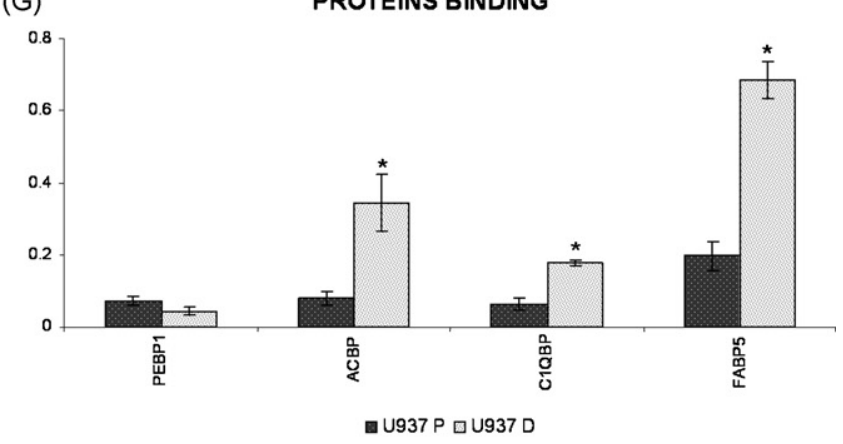

(I)

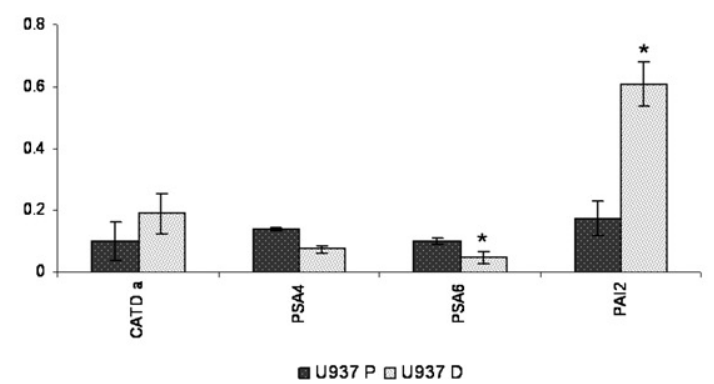

Fig. 7. (Continued).

Interestingly, the differentiated cells display a net decrement of NDKB, a gene product named $\mathrm{nm} 23-\mathrm{H} 2$. The $\mathrm{nm} 23-\mathrm{H} 2$ gene product corresponds to PUF the c-Myc purine-binding transcription factor [20] and plays a role in sustaining unrestricted cell proliferation by inhibiting myeloid cell differentiation in mouse models [21]. In addition, it has been reported that nm23-H1 and nm23-H2 genes are overexpressed in acute myelogenous leukemia cells [22], and that higher level of nm23 in blood are correlated with a poor prognosis in several haematological malignancies [23]. A previous reports by Caligo et al. did already pointed out the role of NDKB in the terminal differentiation of the U937 cells, ascribing to this gene a regulatory effect on c-Myc suppressive mediated cell proliferation and induction of cell differentiation [6]. Our data, while confirming the cited reports, expand the collection of differentiation-associated proteins. Among these, two relevant protein families which positively respond to the differentiations are the Annexins and the S100 proteins. Annexins constitute a well-known multigene family of calcium-regulated phospholipid-binding and membrane-binding proteins, which in vertebrates comprises 12 subfamilies (A1-A11 and A13) with different splice variants. This family of proteins is involved in a variety of membrane-related processes [24], including macrophage phagocytosis [25]. In detail we have found incremented expression of ANXA2 and decrement of ANXA1 and ANXA5, in the differentiated U937 cells.

ANXA2 appears a necessary component of the machinery controlling endosomal membrane dynamics and multivesicular endosome biogenesis in the degradation pathway of animal cells [26]. Moreover, it has been reported that ANXA2 on the surface of endothelial cells and monocyte-macrophage can function as a coreceptor for plasminogen and tPA, thereby acting as a positive modulator in the fibrinolytic cascade and extracellular matrix remodelling (reviewed by [27]). Conversely, ANXA1, one of the gene products involved in cell proliferation, is decremented in U937differentiated cells [28]. The decrement of ANXA5, instead, has not a clear explanation at present.

The increment of six members of the S100 protein family (including isoforms) was also observed. In detail the gene products of the S100 protein forms of our proteome, are S100A4, S100A6, S100A11 and S100A13. S100 proteins are small, acidic proteins of $\mathrm{Ca}^{2+}$ binding proteins, found exclusively in vertebrates. Presently, at least 25 members of the S100 protein family are recognized in 

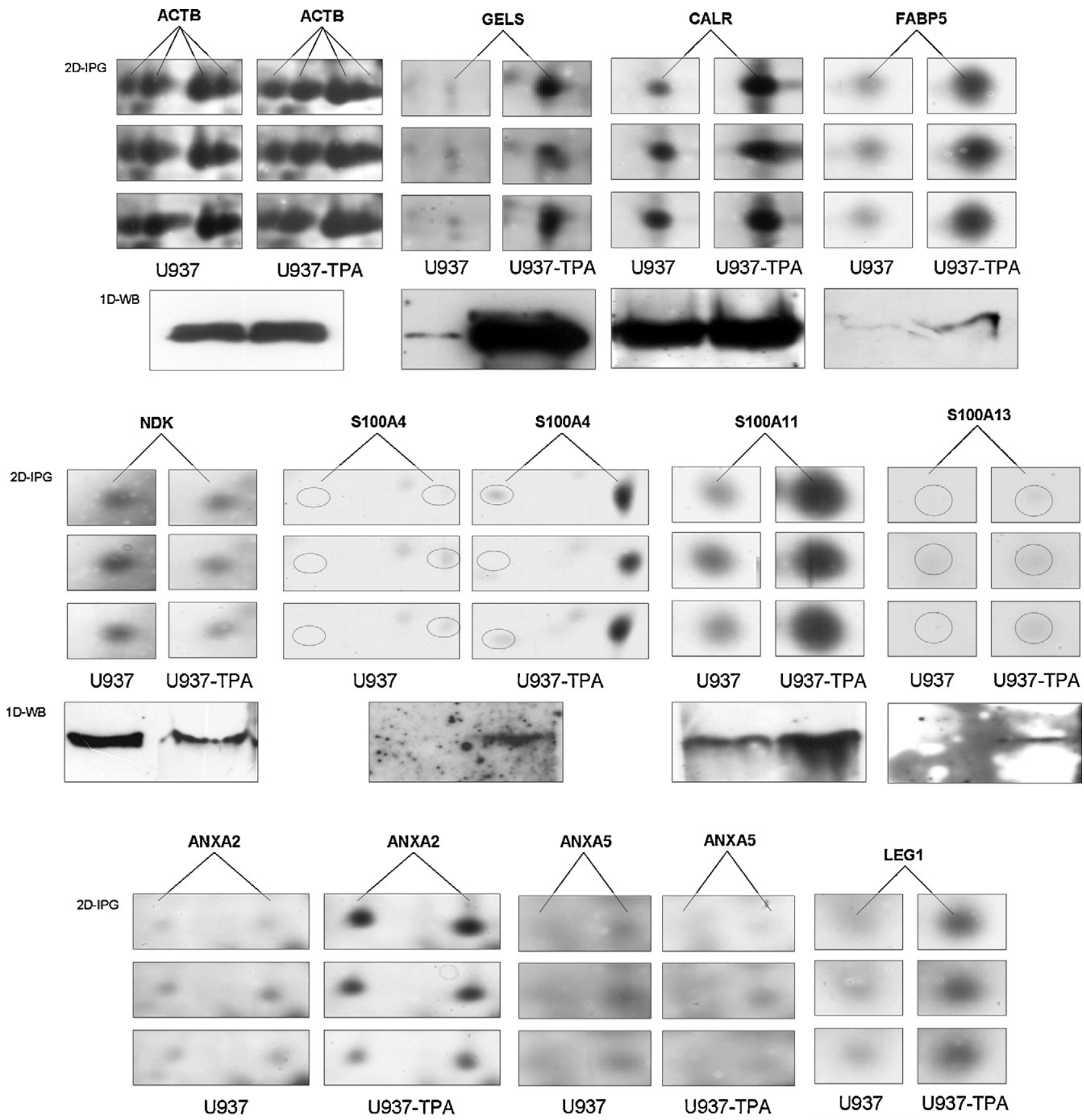

U937-TPA

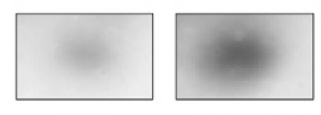

1D-WB
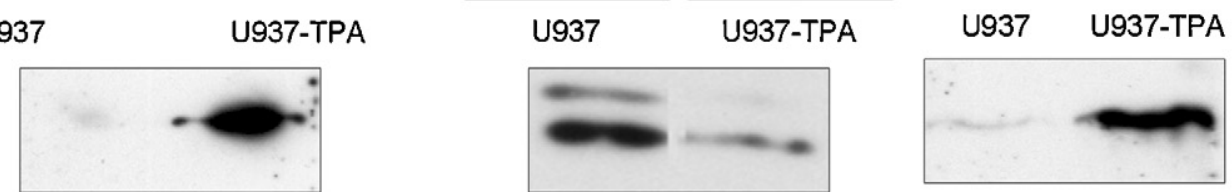

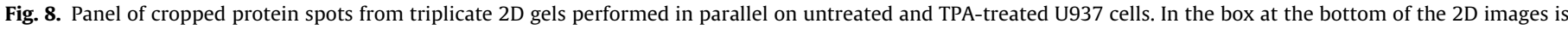
reported for each protein the paired 1D-WB with the proper antibody, namely: ACTB, GELS, CALR, FABP5, NDK, S100A4, S100A11, S100A13, ANXA2, ANXA5 and LEG1.

humans, 21 of them are coded by genes clustered at chromosome locus 1q21.

S100 proteins form homo- and hetero-dimers, and even oligomers, and are expressed in tissue and cell-specific manner, suggesting that each S100 protein has different function and role [29]. Indeed, it is well documented that $\$ 100$ proteins have a broad range of intracellular and extracellular functions. Intracellular functions include regulation of protein phosphorylation, enzyme activity, calcium homeostasis, regulation of cytoskeletal components and regulation of transcriptional factors, so they are involved in several biological processes including cell cycle regulation, cell growth, cell differentiation, and motility [30]. Extracellularly they act in a cytokine like manner through the receptor for advanced glycation end products (RAGE) [31]. To our knowledge, this is the first report on the global expression of several S100 members in the monocytic/macrophage cell lineage, and more information is needed to fully understand their role in the macrophage function. Some members of S100 family act as partner of ANXs. For example, it has been reported that protein S100A4 induces angiogenesis through interaction with ANXA2 on the sur- 
face of endothelial cells, and accelerate local plasmin formation [32].

A further significant correlation we observed in the differentiated cells was the increment of two other proteins, related to the phagocytic machinery. These are calreticulin and the glycoprotein $\mathrm{gC} 1 \mathrm{qBP}$. Calreticulin is an endoplasmic reticulum-luminal calcium-binding chaperone involved in various cellular functions. Some authors have proposed that calreticulin can translocate to the cell surface taking part, with the glycoprotein $\mathrm{gC} 1 \mathrm{qBP}$, to the multi-ligand receptor system for the collectin protein family [33]. This protein family, also termed "defense collagen" family, includes the complement proteins $\mathrm{C} 1 \mathrm{q}$ and mannose binding lectin (MBL), as well. These proteins, through their receptors, are involved in phagocytic pattern recognition and may play pivotal roles in immediate and long-term protective immune functions [34]. Moreover, it has been reported that calreticulin, in conjunction with the scavenger receptor CD91/LRP, is able to initiate macropinocytosis and uptake of apoptotic cells [35].

Interestingly, the presence of a $\mathrm{C} 1 \mathrm{q}$ receptor on the $\mathrm{U} 937$ cell line was identified by fluorescence in early 1984 [36]. More recently it has been reported that its expression in the monocytic cell lineage is maturation dependent [37].

In addition to calreticulin, there is evidence that other heat shock/chaperone proteins are involved in the phagocytic machinery [38]. In our system, we have also detected an increment of the heat shock protein GRP94 and of the heat shock protein 70 (HSP71). GRP94 is localized in the endoplasmic reticulum, and has a variety of roles in mammalian organisms. As a chaperone, it is involved in protein folding in the endoplasmic reticulum [39]. Moreover, it also associates with calreticulin driving intracellular (poly) peptides into the major histocompatibility (MHC) class I presentation pathway [40]. Besides, GRP94 and HSP70 exert a stimulatory effect on phagocytic functions of macrophages [41,42].

Conclusively, present investigation has provided a significant panel of proteomic markers, including both over- and downregulated proteins. The first include proteins involved in biological pathways relevant for the macrophagic functions, as surface and membrane traffic, phagocytosis and antigen-presenting pathways. The second ones include gene products playing a key role in the control of cell proliferation and metabolism.

We suggest that present data may contribute significantly to the knowledge of biological pathways involved in myelo-monocytic cell differentiation that may be of valuable utility for haematological diseases in which the leukocyte differentiation is impaired or compromised.

\section{Conflicts of interest}

Authors declare no conflicts of interest.

\section{Acknowledgements}

This study was supported by “ 5 per mille" contribution to Centro di Oncobiologia Sperimentale (COBS), Palermo, Italy. The authors wish to thank Prof. Salvatore Feo for his suggestions and helpful discussions and Prof. Ida Pucci-Minafra for continuous support to the experimental work and for the critical reading of the manuscript.

Contributions. All authors participated to the conception, design, interpretation and elaboration of the findings of the study. All authors read and approved the final manuscript.

\section{References}

[1] Sundström C, Nilsson K. Establishment and characterization of a human histiocytic lymphoma cell line (U-937). Int J Cancer 1976;17:565-77.
[2] Harris P, Ralph P. Human leukemic models of myelomonocytic development: a review of the HL-60 and U937 cell lines. J Leukoc Biol 1985;37:407-22.

[3] Olsson IL, Breitman TR. Induction of differentiation of the human histiocytic lymphoma cell line U-937 by retinoic acid and cyclic adenosine 3':5'-monophosphate-inducing agents. Cancer Res 1982;42:3924-7.

[4] Olsson I, Gullberg U, Ivhed I, Nilsson K. Induction of differentiation of the human histiocytic lymphoma cell line U-937 by 1 alpha,25-dihydroxycholecalciferol. Cancer Res 1983;43:5862-7.

[5] Stöckbauer P, Malasková V, Soucek J, Chudomel V. Differentiation of human myeloid leukemia cell lines induced by tumor-promoting phorbol ester (TPA). I. Changes of the morphology, cytochemistry and the surface differentiation antigens analyzed with monoclonal antibodies. Neoplasma 1983;30:257-72.

[6] Caligo MA, Cipollini G, Petrini M, Valentini P, Bevilacqua G. Down regulation of NM23.H1, NM23.H2 and c-myc genes during differentiation induced by 1,25 dihydroxyvitamin D3. Leuk Res 1996;20:161-7.

[7] Harris PE, Ralph P, Litcofsky P, Moore MA. Distinct activities of interferongamma, lymphokine and cytokine differentiation-inducing factors acting on the human monoblastic leukemia cell line U937. Cancer Res 1985;45:9-13.

[8] Morrissette N, Gold E, Aderem A. The macrophage-a cell for all seasons. Trends Cell Biol 1999; May (9):199-201.

[9] Bradford MM. A rapid and sensitive method for the quantitation of microgram quantities of protein utilizing the principle of protein-dye binding. Anal Biochem 1976;72:248-54.

[10] Pucci-Minafra I, Cancemi P, Fontana S, Minafra L, Feo S, Becchi M, et al. Expanding the protein catalogue in the proteome reference map of human breast cancer cells. Proteomics 2006;6:2609-25.

[11] Shevchenko A, Wilm M, Vorm O, Mann M. Mass spectrometric sequencing of proteins silver-stained polyacrylamide gels. Anal Chem 1996;68:850-8.

[12] Marcu KB, Bossone SA, Patel AJ. Myc function and regulation. Annu Rev Biochem 1992;61:809-60.

[13] Ezekowitz RA, Sastry K, Bailly P, Warner A. Molecular characterization of the human macrophage mannose receptor: demonstration of multiple carbohydrate recognition-like domains and phagocytosis of yeasts in Cos- 1 cells. J Exp Med 1990;172:1785-94.

[14] Sallusto F, Cella M, Danieli C, Lanzavecchia A. Dendritic cells use macropinocytosis and the mannose receptor to concentrate macromolecules in the major histocompatibility complex class II compartment: downregulation by cytokines and bacterial products. J Exp Med 1995;182:389-400.

[15] Tan MC, Mommaas AM, Drijfhout JW, et al. Mannose receptor-mediated uptake of antigens strongly enhances HLA class II-restricted antigen presentation by cultured dendritic cells. Eur J Immunol 1997;27:2426-35.

[16] Buentke E, Zargari A, Heffler LC, Avila-CariñoJ, Savolainen J, Scheynius A. Uptake of the yeast Malassezia furfur and its allergenic components by human immature CD1a+ dendritic cells. Clin Exp Allergy 2000;30:1759-70.

[17] http://david.abcc.ncifcrf.gov/.

[18] Nyakern-Meazza M, Narayan K, Schutt CE, Lindberg U. Tropomyosin and gelsolin cooperate in controlling the microfilament system. J Biol Chem 2002;277:28774-9.

[19] Wright SD, Detmers PA, Aida Y, Adamowski R, Anderson DC, Chad Z, et al. CD18-deficient cells respond to lipopolysaccharide in vitro. J Immunol 1990;144:2566-71

[20] Postel EH, Berberich SJ, Flint SJ, Ferrone CA. Human c-Myc transcription factor $\mathrm{PuF}$ identified as $\mathrm{nm} 23-\mathrm{H} 2$ nucleoside diphosphate kinase, a candidate suppressor of tumor metastasis. Science 1993;261:478-80.

[21] Okabe-Kado J, Kasukabe T, Honma Y, Hayashi M, Henzel WJ, Hozumi M. Identity of a differentiation inhibiting factor for mouse myeloid leukemia cells with NM23/nucleoside diphosphate kinase. Biochem Biophys Res Commun 1992;182:987-94.

[22] Wakimoto N, Yokoyama A, Okabe-Kado J, Nagata N, Motoyoshi K, Honma $\mathrm{Y}$. Combined analysis of differentiation inhibitory factor nm23-H1 and $\mathrm{nm} 23-\mathrm{H} 2$ as prognostic factors in acute myeloid leukaemia. $\mathrm{Br} \mathrm{J}$ Cancer 1998; 77:2298-303.

[23] Niitsu N, Okabe-Kado J, Nakayama M, Wakimoto N, Sakashita A, Maseki N, et al. Plasma levels of the differentiation inhibitory factor $\mathrm{nm} 23-\mathrm{H} 1$ protein and their clinical implications in acute myelogenous leukemia. Blood 2000;96:1080-6.

[24] Rescher U, Gerke V. Annexins-unique membrane binding proteins with diverse functions. J Cell Sci 2004;117:2631-9.

[25] Fan X, Krahling S, Smith D, Williamson P, Schlegel RA. Macrophage surface expression of annexins I and II in the phagocytosis of apoptotic lymphocytes. Mol Biol Cell 2004; 15:2863-72.

[26] Mayran N, Parton RG, Gruenberg J. Annexin II regulates multivesicular endosome biogenesis in the degradation pathway of animal cells. EMBO J 2003;22:3242-53.

[27] Kim J, Hajjar KA. Annexin II: a plasminogen-plasminogen activator co-receptor. Front Biosci 2002;7:341-8.

[28] Lim LH, Pervaiz S. Annexin 1: the new face of an old molecule. FASEB J 2007;21:968-75.

[29] Donato R. Intracellular and extracellular roles of S100proteins. Microsc Res Tech 2003;6:540-51.

[30] Donato R. S100: A multigenic family of calcium-modulated proteins of the EFhand type with intracellular and extracellular functional roles. Int J Biochem Cell Biol 2001;33:637-68.

[31] Leclerc E, Fritz G, Vetter SW, Heizmann CW. Binding of S100 proteins to RAGE: an update. Biochim Biophys Acta 2009;1793:993-1007.

[32] Semov A, Moreno MJ, Onichtchenko A, Abulrob A, Ball M, Ekiel I, et al. Metastasis-associated protein S100A4 induces angiogenesis through inter- 
action with Annexin II and accelerated plasmin formation. J Biol Chem 2005;280:20833-41.

[33] Ghebrehiwet B, Peerschke EI. cC1q-R (calreticulin) and gC1q-R/p33: ubiquitously expressed multi-ligand binding cellular proteins involved in inflammation and infection. Mol Immunol 2004;41:173-83.

[34] Bohlson SS, Fraser DA, Tenner AJ. Complement proteins C1q and MBL are pattern recognition molecules that signal immediate and long-term protective immune functions. Mol Immunol 2007;44:33-43.

[35] Ogden CA, deCathelineau A, Hoffmann PR, Bratton D, Ghebrehiwet B, Fadok VA, et al. C1q and mannose binding lectin engagement of cell surface calreticulin and CD91 initiates macropinocytosis and uptake of apoptotic cells. J Exp Med 2001;194:781-95.

[36] Arvieux J, Reboul A, Bensa JC, Colomb MG. Characterization of the C1q receptor on a human macrophage cell line U937. Biochem J 1984;218:547-55.

[37] Vegh Z, Goyarts EC, Rozengarten K, Mazumder A, Ghebrehiwet B. Maturationdependent expression of C1q binding proteins on the cell surface of human monocyte-derived dendritic cells. Int Immunopharmacol 2003;3:39-51.
[38] Edwards MJ. Apoptosis, the heat shock response, hyperthermia, birth defects disease and cancer. Where are the common links? Cell Stress Chaperones 1998;3:213-20.

[39] Melnick J, Dul JL, Argon Y. Sequential interaction of the chaperones BiP and GRP94 with immunoglobulin chains in the endoplasmic reticulum. Nature 1994;370:373-5.

[40] Singh-Jasuja H, Toes RE, Spee P, Münz C, Hilf N, Schoenberger SP, et al Cross-presentation of glycoprotein 96-associated antigens on major histocompatibility complex class I molecules requires receptor-mediated endocytosis. J Exp Med 2000;191:1965-74.

[41] Radsak MP, Hilf N, Singh-Jasuja H, Braedel S, Brossart P, Rammensee HG, et al. The heat shock protein Gp96 binds to human neutrophils and monocytes and stimulates effector functions. Blood 2003;101:2810-5.

[42] Wang R, Kovalchin JT, Muhlenkamp P, Chandawarkar RY. Exogenous heat shock protein 70 binds macrophage lipid raft microdomain and stimulates phagocytosis, processing, and MHC-II presentation of antigens. Blood 2006;107:1636-42. 